\title{
RE-SEGMENTING OPPOSITION VOTES IN TURKEY USING A RELATIONAL APPROACH: THE BOXER, THE PRAGMATIST, AND THE VISIONARY
}

\section{Neslihan ÇEVIKK ${ }^{1}$}

\begin{abstract}
This paper studies voting from a relational approach and builds a new model for voter segmentation using qualitative data from Turkey. To operationalize a relational approach in the field, I employed 'switch interviews' with 15 participants recruited from a randomly sampled national poll (March 2020), who in common opted for one of the recently founded parties in Turkey when asked "who they would vote for if there was an election tomorrow". In this new model, the object of inquiry for voter segmentation is neither broad structural traits a voter has (ethnicity, religion, ideology, sexuality, etc) nor atomistic calculations. Instead, it is the actual needs and concerns voters are trying to meet in a system of relations. Drawing from these needs, I identify three relational voter profiles: the Boxer, the Pragmatist and the Visionary. These new relational segments help us better understand the causal drivers for support to the new parties in Turkey and give us clues into the future political debates and shifts in the country. The aim here is not to narrow voter segmentation to a single right approach. Nor the study claims to uncover all opinions /needs of the opposition electors who lean towards the new parties; it certainly does not claim to have scanned all opposition voters in Turkey. Rather, the paper aims to push the boundaries of the existing models by adopting a relational thinking and a new tool, switch interviewing, and build a new model for voter segmentation. Such a push is mandated in part by the changing nature of political engagement and citizenship. The paper makes two original contributions. It proposes a new model for voter segmentation using a relational approach and introduces a new methodological tool, switch interviews, to qualitative research.
\end{abstract}

Keywords: Relational Sociology, Electoral Behavior, Switch Interviews, Justice and Development Party, Turkish Electorate 


\section{İLISSKISEL BİR BAKIŞ AÇISI İLE TÜRKIYE'DE MUHALEFET- SEÇMENLERINIIN YENIDEN KÜMELENMESİ: BOKSÖR, PRAGMATÍST VE VIZYONER}

\section{ÖZ}

Bu çalışma seçmen davranışını ilişkisel bir yaklaşımla ile incelemiş ve Türkiye özelinde yapılan bir nitel araştırma ile yeni bir seçmen kümelemesi (segmentation) modeli oluşturmuştur. İlişkisel analizin alanda uygulaması için bir derinlemesine mülakat tekniği olan 'switch (kayma) mülakatları' kullanılmıştır. Katılımcılar Mart-2020'de yapılan bir ulusal ankete "yarın seçim olsa yeni kurulan partilerden birine oy veririm” diyen 15 seçmenden oluşmaktadır. Yeni partilere oy vermeyi düşünen bu heterojen grup siyasi ve sosyo-demografik farkl11ıklarına rağmen üç ana endişe/ ihtiyaç altında birleşerek üç seçmen profili ortaya çıkarmıştır: Boksör, Pragmatist ve Vizyoner. Çalışma, bir taraftan yeni partilere oy vermeyi düşünen seçmenin bu kararının nedenlerini anlamamıza yardımcı olurken, daha genel olarak ülkedeki olası siyasi değişimin ve ortaya çıkmakta olan siyasi eğilimlerin içeriği ve yönü hakkında da ipuçları vermektedir. Ancak çalışma yeni partilere oy vermeye sebep olan tüm ihtiyaçların temsil edildiği iddiasında değildir. Bunun yerine, çalışmanın ana amacı seçmen kümelemesi için yeni bir model önererek ve nitel araştırmaya yeni bir metodolojik araç sunarak, mevcut modellerin bakış açılarını genişletmektir. Nitekim, bu genişleme 21.yy'ın başından beri tüm dünyada örnekleri artarak çoğalan yeni siyasal katılım ve vatandaşlık tanım ve pratiklerini daha iyi anlayabilmemiz için de zaruridir. $\mathrm{Bu}$ çerçevede, çalışma hem niteliksel araştırma hem de seçmen davranışı literatürüne yeni bir modelleme ve yeni bir teknik sunarak iki orijinal katkı yapmaktadır.

Anahtar Kelimeler: İlişkisel Sosyoloji, Seçmen Davranışı, Switch Mülakatları, Adalet ve Kalkınma Partisi, Türkiye Seçmeni 


\section{INTRODUCTION}

In the last decade or so, across the world, electoral results that "no one saw coming" have become more the norm and less the exception. With that, I mean election outcomes that went opposite to the predictions by polls, media, pundits, and seasoned politicians.

Just to name a few, consider the rise of Kasi Said in 2015 Tunisian elections; Trump's victory in 2016 US elections; Sinn Féin's coming to power in Ireland's 2020 elections; Orban backed Fidezs's defeat in 2020 in Hungary at five major cities, including Budapest; British citizens' decision to leave Europe Union (2016). Also consider İmamoğlu's win of local elections in İstanbul (2018), Turkey, getting majority support even from conservative districts, Ümraniye being one of those, viewed typically as castles of the incumbent Justice and Development Party (JDP).

Results in each and every one these elections were defined commonly by such terms as strange, shock, astonishing, and electoral quake. Yet, once results were settled, explanations for why such results in fact made sense emerged with ease and fast. In Tunisia, for example, the 'miracle' of Kasi Said's ascendence was attributed post-election to the growing desire of the populace for an uncorrupt leader, whereas Sinn Féin's win was later attributed to the wide upsets about housing and health care. One cannot help but wonder why the political industry, either in Tunisia or Ireland, has failed to capture an upcoming electoral wave against anti-corruption, or the impact of a growing popular dissent about housing and health care problems.

The answer is not simply about measurement errors. Rather, it lays in what we select to measure as drivers or determinants of electoral behavior, and this selection is informed by dominant theoretical assumptions about voting and voters.

Historically, three theoretical models have shaped the social scientific study of voting and electoral behavior (Antunes, 2010, p.146): the sociological model, which takes socio-demographic properties as the main determinant of electoral choice (Lazarsfeld et al., 1968); the psychosocial model, which takes group-affinity as the main determinant of electoral choice (Campbell et al., 1960); and the rational 
choice model, which takes voters' rational calculations as the main determinant of electoral choice (Downs, 1957). Built on social theory's classical dualism of structure versus agency, these models either give primacy to structure over individual or to individual action over structure. That is, they either assume the political content of individuals from social attributes or atomistic personal interests.

Differing from these models, this paper studies voting from a relational approach and builds a new model for voter segmentation using qualitative data from Turkey. By a relational approach, I mean in particular three things: (1) stepping out of the classical dualism of structure versus agency, (2) understanding social action and phenomena to be processual, and (3) to be embedded in a matrix of relationships and a web of fields.

In this relational model, the unit of analysis for voter segmentation is neither broad structural traits a voter has (ethnicity, religion, ideology, sexuality, etc) nor atomistic calculations. Instead, the object of inquiry is the actual needs and concerns (a problem to be solved or a progress to be made) voters are trying to meet through a particular electoral action, which emerge in a particular context and system of relations.

The aim here is not to narrow voter segmentation to a single right approach; rather, the paper aims to push the boundaries of the existing models on electoral behavior and urge us think beyond 'natural' dispositions or atomic calculations. By focusing on voter needs and the system of relations that create those needs, we can get closer to the causal drivers of electoral choice. That is, we may be able to capture, for example, what many have missed in Tunisia, Turkey, or Finland whether it be growing reaction against corruption, concerns about children's future job security, or the need for national or financial security.

In what follows, the reader will first find a brief discussion on the dominant models of electoral behavior and why and how a new model based on a relational thinking can add to our understanding of voting. I then introduce the methodology and design of the qualitative field work. While having a theoretical understanding that the social is made of processes is the starting point for any relational research, we 
also need appropriate methodological tools to operationalize that understanding in the field. To conduct the qualitative work, I employed 'switch interviews', a specific type of in-depth interviewing, originated in product design (Christensen et al, 2016); but is now used in social policy development including poverty reduction (see for example, Christensen et al., 2019) and education (see for example, Horn \& Moesta, 2019).

While still foreign to social scientists, switch interviewing can prove to be quite useful for qualitative work, especially for relational research with its specific style of interviewing designed to follow processual interactions.

Briefly, switch interviewing is aimed at creating a timeline of decision-making by mapping the chains of events that shaped and determined the vote decision for an elector. By revealing chain of events, the timeline helps us map out both the processes involved in decision making and the particular context and web of relations in which that decision is embedded. It reveals, more specifically put, how the electoral decision hangs together with and across matrix of relationships, and actors: interactions not only with the political elite and media but family, employees, employers, or bureaucratic institutions, consumption and markets, leisure and everyday life, and a number of other interactions. As such, switch interviewing helps the researcher "...to get close to the thing entire [and] to view processes from multiple even opposing perspectives..." (Desmond, 2014, p.558).

To conduct switch interviews, I recruited 15 participants from a randomly sampled national poll, conducted in March 2020 by OPINIO, who in common opted for one of the recently founded parties in Turkey when asked who they would vote for if there was an election tomorrow (see section 3.2 for more on sampling). Therefore, the findings here do not represent the whole range of electors that oppose the incumbent, but only those who are unhappy both with the current incumbent Cumhur Coalition and the mainstream opposition, Millet Coalition, looking therefore for a new political solution after being ruled by the JDP for almost 20 years. This is a deliberate selection. Understanding the needs and concerns of opposition electors who are in quest for a new political solution (a new political party or leader) will 
give us clues into the content and direction of political change and emerging political patterns in the country.

The in-depth switch interviews resulted in three categories of voter needs that electors who consider voting for the new parties are trying to address. Drawing from these needs, I profile three relational voter profiles: the Boxer, the Pragmatist and the Visionary. Each new relational segment brings together various former vote patterns and political identities, including those identities that would conventionally be counterposed and expected to have opposing vote options. For example, the category of Boxer is composed of electors who self-identify as Kemalist, Social-democrat, Conservative, Islamist, and Nationalist. Similarly, the new relational segments are composed of respondents coming from a variety of socio-demographic attributes.

Briefly, the Boxer is composed of the electors who think of themselves as "losers" exposed to a series of misfortunes and they attribute those misfortunes to the incumbent's failures. What they want now is to knock off (overthrow) the incumbent at whatever cost — hence the term boxer-, without, however, having a specific vision for what should come next for the country.

The Pragmatist include those electors who seek the establishment of socially just system. This is not egalitarianism, but a pragmatist attitude. In a context perceived to be hyper-clientelist (yandaşlık), pragmatists have to come to believe that individual welfare requires social welfare. As such, rather than becoming the new clients (yandaş) replacing old ones, what they want now is the dismantle clientelism for once and all. Pragmatists think that whatever the partisan group becomes the patron, the circle of clienteles eventually shrinks and excludes at the end not only the average citizens but also those who vote or even are emotionally attached to that patron party.

The visionary, finally, constitutes the electorate who envision a Turkey joined finally to the league of rich democracies. The visionary emerges in a context where the incumbent is perceived to expose the country to severe financial and security-related risks with direct costs to citizens. What they want now 
is a game-changer who not only would protect the country against international rifts but 'make Turkey a great country', in turn improving opportunities for individual wealth and the quality of life.

After detailing these segments, I conclude the paper with implications for social theory on electoral behavior as well for democratic politics, particularly for Muslim societies. The paper aims to push the boundaries of the existing models on electoral behavior and suggest a viable analytical alternative. This is mandated in part by the changing nature of 'being political', as evinced globally in youth movements, from Arab Spring to Occupy LA to the Umbrella Movement in Hong Kong, which all came forward with Do-It-Yourself/DIY-style (see Pickard 2019, for more) of political engagement and a new definition of citizenship. Finally, the paper makes two original contributions. It proposes and experiments with a new model for voter segmentation using a relational approach, therefore contributing both to the literature on relationalism and scholarship on electoral behavior. Secondly, it introduces a new methodological tool, switch interviews, to relational qualitative research. While social network analysis (SNA) has been utilized by relational scholars for empirical work, elaborate methods for fieldwork is still being developed. Switch interviewing can provide one such method or roadmap that can reveal not only networks but other forms of relational structure that are not limited to social ties.

\section{A RELATIONAL APPROACH TO ELECTORAL BEHAVIOR}

Although the idea that 'social is relational' has a long history in sociology (Simmel, Hegel, Foucault, Bourdieu, Ellias, and many others; see Kasapoglu, 2019), scholarly work that go by the name of 'Relational Sociology’ (Emirbayer, 1997; Dépelteau, 2008; Crossley, 2011; Donati, 2011) as a specific stream of thought emerged in the 1990s. Since then, relational thinking has expanded into other disciplines too, including archeology (Fowler, 2013), ethnography (Desmond, 2014; Gupta, 2012; Tsing, 2005), and political science (McClurg \& Young, 2011).

Applications of relational thinking to political phenomenon have proved to be particularly useful both for operationalizing key political concepts, such as power and developing new policy insights for thorny issues, such as immigration (Tekin Babuç and Müjdat, 2019) and terrorism. In the case of radicalism, 
for example, della Porta (2018) has shifted our attention away from 'structural factors (modernization, poverty, tradition, etc) and individual factors (vulnerability, personality traits, etc.) towards interpersonal processes, transformatory events, confrontations, and encounters, uncovering as a result what activates people and how non-violent groups turn to violence and radicals into terrorists.

Relational studies in the political field also covered electoral behavior but focused mostly on social networks analysis (SNA). By integrating electors into various social contexts and information environments, these studies paved the way for alternative approaches that stepped out of the dualism of structure versus agency dualism. This paper follows the track paved by these studies but also contributes to them by exploring electoral behavior not only in terms of social ties but also as a processual and embedded phenomenon. This approach results in a new model of voter segmentation. In the rest of the paper, the reader will find what such an application new model means and why the resulting model of voter segmentation is useful.

\subsection{Rejection of Classical Dualisms}

For centuries social theory has been informed by a dualism between 'structure versus agency', where structure refers to "the constraining effects of society on human individuals" and agency to "the ability of individuals to freely determine their own actions" (Powell \& Dépelteau, 2013, p.3). Those who give primacy to structure see higher-level social entities to be causally significant, impelling and determining individual and collective action. Those who give primacy to agency, in contrast, view social entities as by-products of individual motivations, interests, dispositions.

This divide has also shaped the social scientific study of political and electoral behavior (List \& Spiekermann, 2013). In fact, the three historical models of electoral behavior is built on this very separation: the sociological and the psychosocial models view political preferences as outcomes of structural patterns (Lazarsfeld et al., 1968), whereas for the rational choice model voting is an individual act and political preference is determined by an elector's calculations, interests, and motivations. 
In the sociological model, structural patterns refer to socio-demographic properties of an elector (age, income, education, etc) and social cleavages that are historically rooted in a given society — such as the center-periphery, industrial-agricultural, and state-church divides (Lipset \& Rokkan, 1967). The model's core idea is that social properties and cleavages translate into political dissent and constitute the most durable, in fact frozen, bases for political and electoral contestation (Antunes, 2010; Zielinski, 2002).

Similar to the sociological model, the psychosocial model too emphasizes group-traits but adds an emotional dimension to electoral behavior through the concept of partisanship. Partisanship, it is argued, is formed long before one develops political awareness via "a socialization process, influenced by the values and attitudes of family, colleagues and peers" (Antunes, 2010: 154; also see Miller et al., 1996). This means what determines vote choice is group cohesion; an emotional attachment to one's group leads to a genuine form of social identification with a party that corresponds to that group (Green \& Baltes, 2016). In sum, while in the sociological model, people vote from within their social group, in the psychosocial model they also vote for their social group (Lazarsfeld et al., 1968).

Whether emphasizing structural voter groups or a strong Gestalt, both of these models result in voter blocs grouped and separated based on broad attributes like gender, class, sexuality, occupation, political identity, ethnicity, religion, or some other characteristic; these attributes predict an elector's vote choice.

The group-based thinking — center vs periphery and the resulting partisan divisions — has especially dominated scholarship of electoral behavior in Turkey. Inherited from the Ottoman state structure, this divide, it is argued, (Mardin, 1973), continues to determine contemporary voter preferences (economic voting), resulting in two blocs of voters: a nationalist, urban Kemalist center with secular values pitted against an ethnic and regional periphery with traditional and religious values (Gidengil \& Karakoç, 2016). The popularity of this framework is not startling for it provides both the scholars and political leaders with seemingly neat and preconstructed voter groups, whose political preferences are historically branded, and being historically rooted, their validity, presumably, requires no further curiosity. 
This seemingly practical and acquitted decision, however, poses various problems. It is not that center versus periphery and associated divisions (religiosity, ethnicity, gender) do not exist; nor it is that those divisions do not work as objects of political inquiry. Rather, similar to what Desmond (2014) writes about group and field-based ethnographies, such as poor black families or a Chicago community, these structurally anchored groups work 'too well'.

To begin with, these structural vote groups are viewed as “...internally homogeneous, bounded, and externally distinctive entities" (Desmond, 2014, p. 551). This view, however, is far from reality as groups and identities, the working-class, leftists, Kurds, Muslims or others, are marked with fluidity, heterogeneity, conflict as well as ambivalence and ambiguity. Even the most taken for granted sociopolitical category of ideology, for example, is documented, in the West and elsewhere, not only to be multidimensional (Feldman \& Johnston, 2014) but also to be ambivalent: “...many citizens simultaneously maintain conservative economic attitudes and liberal social attitudes (and vice versa)" (Treier \& Hillygus, 2009). A similar ambivalence is captured among Turkish citizens by Y1lmaz et al. (2016), showing a lack of clarity among self-defined leftists (liberals as well) whether they even agree on basic values. A much broader issue observed by many is the significant gap separating politically sophisticated citizens from laymen in terms of ideological thinking and its impact on voter preferences (Kinder and Kalmoe, 2017; Lupton et al., 2012).

Second, although “...these models recognize the historical construction of groups, they do not document the processes or everyday maintenance of group construction" (Desmond, 2014, p. 552). Yet contrary to this:

...social phenomena are sustained and enacted in the relations that exist between social actors, such phenomena are never static, but instead are in a continual process of being made and remade within specific emergent social contexts... (Abbott, 2020, p.46).

A stream of research, for instance, has illustrated how broad processes such as digitalization, immigration, and globalization create new social cleavages in fact upending traditional ones. Öniş 
(2007), for instance, has documented the rise of a new cleavage in Turkey, 'global conservatism' versus 'defensive nationalism', where certain elements that were seen as sure and fixed symbolic dividers are now reversed (e.g., religious periphery adopting global orientations). Others have shown how these processes have progressively misaligned social structural groups and parties (Von Schoultz, 2017; Dalton, 2000); yet others pointed out to an on-going fragmentation of social class. All of these examples attest to fluid and continual reconstructions of structural groups.

Finally, in structural models it is not the individual or groups who do the acting, but their attributes. In other words, the variable attributes (religiosity, ethnicity, age, income) are casted as actors creating outcomes by mandating people's preferences (Abbott, 1995). This is because structural categories are reified, being treated as 'things' in themselves external to and beyond the interactions in which they are sustained (Abbott, 2020). Within this framework, if we were to talk about Kurdish or Muslim voters, we would actually be talking about not people but ethnicity or religion as external forces acting in a predictable way. The critique here is not that individuals must be seen as detached from the society. On the contrary, individuals and their action are shaped by durable social relations (gender relations or relations of power). At the same time, however, “...even the most enduring and pervasive facets of the social world, which feel so external to the individuals whom they influence, are in fact composed of the relations that exist between actors" (King, 2004 in Abbott 2020, p. 50).

These theoretical problems unfold in practical terms as well. Traits-based thinking does not explain why individuals from a certain social group vote according to what one would expect of individuals belonging to different social groups. Similarly, psychosocial model does not explain why a significant number of voters vote for a party other than the one they identify with. Additionally, both models also have difficulty in explaining what causes people to be undecided or to refrain from voting (Antunes, 2010).

Proponents of the Rational Choice Model claim that a shift in attention towards individual action can provide better answers to these questions. Taking individual human action as the elementary unit of 
social life and thus analysis (Elster, 1989, p.13), the rational choice model explains electoral behavior through self-interest; namely, maximization of the desired outcome. This prevalently takes two forms in the literature: position preferences — people vote for parties they agree with and economic voting people vote for parties that provide good economic performance (McGann, 2016).

The idea that the voter has preferred $\mathrm{Y}$ because $\mathrm{Y}$ is more advantageous is an appealing idea for it provides what appears to be a complete conception of action (Coleman, 1986) and hence seemingly doing away with the black boxes that mark structural accounts (Boudon, 1998). As such, it is not surprising that the model, in the last few years, has attracted a large number of scholars studying Turkey and other Muslim majority contexts along with the increased access to individual level survey data.

Yet, while breaking off from the problems of structural approaches, the rational choice model is trapped by other problems, rooted in the same dualism of structure versus agency. An obvious problem regards the process of decision-making. To make the most optimum choice, a voter needs to know in detail all policy positions and actions, but it takes considerable effort to comprehend and calculate all the consequences. (Antunes, 2010). The model tries to overcome this obvious problem by referring to partisanship and ideologies functioning as heuristics and cognitive shortcuts (Antunes, 2010). The natural next question is that how does one come to adopt a particular policy position (let's say an antiimmigration stance) to begin with? The model has no answer to that given the detached, individualistic agentive capacities it ascribes to individuals (Abbott, 2020). At the end, the model loops back to structural and group-based accounts; the very black boxes it claims to overcome.

This is not to "...discount the fact that individuals engage in social practice from subjective standpoints, modes of action, wants, ... strategies that are relatively distinct, and which they recognize as being their own" (Abbott, 2020, p.64). Nevertheless, these subjective wants or strategies are shaped and moulded by durable social relations; "the individual and her action is constituted in a continuous process of relational interaction" (p.60). 
Another crucial issue regards assumptions about economic voting and its underlying principle of instrumental rationality. According to this, voters make decisions based on economic and bottom-line concerns (such as social assistance). Yet, similar to ideological thinking not all voters have the national economy on their political radar screen (Erikson, 2004). Some scholars have used the term 'values voters' referring to voters who are concerned primarily about social, rather than economic, issues (Lupton et al. 2012, p. 492). For example, Gidengil \& Karakoç (2016) has found independent effects of perceptions of greater democratization, affirmation of the party's securitization of the Kurdish issue, and satisfaction with the EU negotiations on the JDP's electoral success in the beginning of its second term (2007-2010). Hence, rather than instrumental rationality, people may vote for defense of principles, ideas, values, or lifestyles they endorse-which again raises the question of: why do voters endorse those principles?

By limiting its focus to the maximization of position and economy related interests, instrumental rationality, also seems to be separating the political arena and electoral behavior from other spheres and networks of society. Yet people come to make an electoral decision for a variety of reasons broadly embedded in everyday life (Kinder \& Kalmoe, 2017). Some of these reasons may be latent, not being expressed in popular commentaries and may not even be conventionally considered as "political issues'-defined as issues perceived to be requiring governmental action (Van der Brug et al., 2015). Instrumental rationality and methodological individualism fail to cover the broad range of outcomes voter may be pursing.

To recap, neither structural nor individualist models seem to able to get to the bottom of electoral behavior. While they suggest certain correlations, correlation is not causation. To explore if there can be an alternative model that could get us closer to mechanisms underlying voting, we first need to transcend the limitations of structure versus agency dualism by conceptualizing both as belonging to the same order of reality, a relational order (Powell \& Dépelteau, 2013). That is, we need to understand “...the individual as fundamentally and inextricably constituted by social relations while simultaneously 
seeing 'social structure' as only existing in the relations that exist between interacting individuals" (Abbott, 2020, p. 47).

\subsection{Process-Based Thinking and Embeddedness/ How Things Hang Together}

Once we step out of the dualism of structure versus agency and view social action and phenomena as a result of a flow among the individual, institutions, and structure (social relations such as gender, ethnicity, form of economic government), the focus of inquiry becomes that flow itself. In other words, the elementary unit of analysis shifts from reified structural forces or the minds of self-propelling agents to “...relational processes of interaction between and among identities" (Desmond, 2014, p.553).

The preeminent scholarly tendency, however, is to "interpret the changeless aspects of all phenomena [fixed attributes such as race, class, or sexuality] as the most real and significant" (Desmond, 2014, p. 552). This is because those unchanging categories are thought to have internal stability and entities (the individual, the state, collectivities, etc) within those categories are thought to act predictably under normal conditions (Somers \& Gibson, 1994).

Following this line of thought, we must then expect such features as being of Kurdish origin or being a self-defined devout Muslim to explain "[one's] interest and action unproblematically" (Emirbayer, 1997, p.308), compelling a particular political content. Ellias has termed this view "process-reduction." (Elias, 1978): thinking of and speaking about social phenomena and people to be both static and uninvolved in relationships (Desmond, 2014).

Yet, letting religion, class or another attribute to stand for a determinative interest, or experience is problematic both analytically and normatively (Somers \& Gibson 1994, p.37). Normatively, it leads to essentialism in cultural studies (for example, Islamic exceptionalism), in international studies (for example, the clashes of civilization thesis), and in policy making as well, normatizing society's devaluation of certain groups (for example, French state's view of all devout Muslim citizens as potential radicals) (Desmond, 2014). 
Analytically, when we presuppose a group's existence, we also assume that a particular attribute (Kurdishness, religiosity, blackness, etc.) to be the most salient trait of the members of that group. Yet, would not we then be reducing individual action and interest to a single vector, whereas individuals may be oriented to “...multiple vectors (e.g., familial, social, religious, occupational) at different points in time" (Desmond, 2014, p. 564). Second, would not we then be assuming that a given attribute has a homogenous, universal meaning and is experienced homogeneously by all members across time and space?

There are surely correlations between certain traits and political preferences, yet not only correlation is not causation but also how these traits may be compelling people to certain preferences are left undocumented. If ethnicity impels someone to vote in a certain way than what belonging to that ethnicity means and how that meaning directs one's preferences would need to be explained and substantiated. Otherwise, we would be viewing ethnicity or other structural traits as forces that “...mechanically work out their independent logic" (Bourdieu \& Wacquant, 1992, p. 8, also see Kasapoğlu, 2019).

Take the example of religiosity. While as a fixed attribute, religion is typically associated with conservatism, religious conservatism has not been the only form of religious expression in the political arena. As Elff and Roßteutscher (2016) have documented, public expression of religion has taken the form of humanism, pacifism as well as an affirmation of the welfare state, typically associated with the left, which is typically associated with secularity. Protestants in Europe too have displayed a diversity of expressions, ranging from affirming monarchy to demands for self-determination (2016). In Muslim majority contexts too, this static view of Islam as a predictable group boundary has been challenged. In 2000, $80 \%$ of Egyptians said in a survey they favored the implementation of Sharia law but support to Muslim Brotherhood (MB) did not match up to that number at all. MB's success came five years later when importantly it had already trimmed its political fervor down for the establishment of a Sharia-state (Kurzman \& Naqvi, 2010). 
This is not at all to suggest religion, or other traits, are essentially epiphenomenal. Rather, I try to show that "things [including religion] are what they are because of their location and movement in a network or system of forces; they do not assume a fixed and constant position in the network because of their essential properties" (Fuchs, 2009, p.16). It is precisely because of this fluidity, mutability, and relationality, and boundedness of things by dimensions of time and space (Ellias, 1978) that taking processes as the unit of analysis is necessary.

In inquiries of electoral behavior too, we need to build a processual understanding of voting. One way to do this is to focus our attention to the actual needs and concerns of the voters, which they are trying to meet by voting in a certain way (or not voting at all). Put differently, we need to shift our attention away from what broad traits a person has to what the person does in particular conditions throughout electoral decision making.

Another advantage a processual approach is that it allows the analyst to see how individual political action as well as broader political patterns are embedded in networks and relationships reaching well beyond the political field and conventionally defined political issues.

A good example is can be found in Tsing work on deforestation in Indonesia, as pointed out by Desmond (2014) as well. Tsing's ethnography (2005) shows that a comprehensive understanding of deforestation is not limited to a particular mountain and local actors, but emerges and takes place in a milieu of global connections across multiple fields of life, from global investment practices to global network of environmentalists, international governmental organizations, capitalization of leisure (adventure sports) as well as democratic politics.

In brief, what distinguishes relational work, whatever its object may be (technology, political protest, radicalism), is that "the point of fieldwork becomes ...to show how things hang together in a web of mutual influence or support or interdependence" (Becker, 1996, p. 56 in Desmond, 2014). In studying electoral behavior, a comprehensive exploration requires the analyst to "follow connections, associations, and... relationships" (Marcus, 1998: 81 in Desmond 2014). The interviews here too, as 
will be detailed and exemplified later, revealed that political decisions were embedded in a complex associations and experiences, from becoming a first time car owner and realizing for the first time how expensive gas is to desires for social and political change intensified by citizens' ability to view how others live in the world through social media and communication technologies.

By focusing on voter needs and what the voter does instead of his-her traits or partisan affiliations, we can then get closer to describing both the causal drivers of electoral choice and how electoral decisions are made in practice. That is, we may be able to capture, for example, what many have missed in Tunisia or Finland - whether it be growing reaction against corruption, concerns about children's future job security, or the need for national or financial security.

\section{METHODOLOGY AND DATA: SWITCH INTERVIEWING}

\subsection{Switch Interviews}

Having a theoretical understanding that the social is made of processes is the starting point for any relational research, yet to operationalize that understanding in the field we also need appropriate methodological tools. Methodological tools determine the analytical possibilities or explanatory structures available to any researcher (Somers, 1998, p. 769): whether we are able to attune our research to the relational nature of social reality.

The paper employs switch interviewing - originated in product design but has been adopted by social policy development more recently —is one such specific tool. While switch interviewing is still foreign to social scientists due to disciplinary differentiation between academic and market research, it can prove to be quite useful for qualitative work, especially for relational research with its specific style of interviewing designed to follow processual interactions.

In product design, market research typically focuses either on consumer traits (what we view as structure in this paper: young consumers, middle class consumers, etc) or to product features (what we view as individualist needs in this paper) (Christensen and Day, 2016). Switch interviewing differs from both approaches and focuses instead on the basic needs or struggles (a problem to be solved or a progress to 
be made) consumers have that emerge in and created by a particular context. By understanding that context and the need, switch interviewing reveals the causal drivers of consumer action (why someone buys ice-cream) rather than focusing on correlations (ice cream is generally bought by young people).

When applied to electoral behavior similarly, switch interviewing is not focused on explaining what social structural categories the voter belongs or how he-she is trying to maximize a certain self-interest. Rather, it aims to discover needs or struggles that emerge in a particular context and which the voter is trying to cater by electoral action. To uncover that need, the interview asks a specific set of questions, each aimed of at helping the respondent to narrate the set of events that shaped his-her vote option:

"Tell me all the details around when you first started thinking about voting for that party? Who were you with? What else was going on in your life at that time? When did you finalize your decision? The first time you thought there needs to be a new party, what events led up to that moment? Why don't you vote again to your former party?"

At the end, switch interviews result in voter categories not around broad traits nor atomistic interests but common needs and concerns voters experience and try to address by finding their vote option.

As switch interviewing follows actual processes experienced by the voter in her-his coming to a decision, it also allows us to follow the voter's decision across a matrix of relationships, and actors, thus revealing how things hang together in electoral decision making: interactions not only with the political elite and media but family, employees, employers, or bureaucratic institutions, consumption and markets, leisure and everyday life, and a number of other interactions.

\subsection{Recruitment of Participants and Sampling}

The study aims to uncover needs voters are trying meet by leaning towards the new parties. It logically follows that the sample should be composed of those electors who opt for one of the newly formed parties as their vote option for the next election. Opting for a newly formed party also and necessarily means switching from past political behavior to a new one; after all, most of these electors voted for 
other parties in the previous election and some simply refrained from voting. By reflecting the diversity of past political behavior in the sample, we can understand what needs are causing the electors to drop previous behavior and adopt a new one. As such, the sample should be composed of voters who in the previous elections voted for parties of the Cumhur Coalition, that of the Millet Coalition, as well as those who did not vote in the previous election. Following these criteria —opting for new parties as the very next vote option and previous electoral preferences-, 35 names were drawn a randomly sampled national poll, conducted in March 2020 by OPINIO.

Among the 35 initial names, however, only 25 participants agreed to be interviewed for the study. Despite this initial agreement, some participants among those 25 ended up being 'no shows', whereas some dropped out of the study (throughout the fieldwork) indicating discomfort about revealing information on their political preferences. For example, a number females dropped out saying that their spouses did not approve their participation.

At the end, the study was conducted with 15 participants. The below table demonstrates former vote options of the participants. It also shows that they are coming from a diversity of self-defined political identities.

Table 1. Former Vote \& Political Identity

\begin{tabular}{|c|c|}
\hline Former Vote & Will Vote for the New Parties \\
\hline Cumhur Coalition & 7 \\
\hline Millet Coalition & 4 \\
\hline Did not vote & 4 \\
\hline Total & $\mathbf{1 5}$ \\
\hline Political Identity & 5 \\
\hline Kemalist or Social-democrat & 5 \\
\hline Conservative or Islamist & 4 \\
\hline Nationalist & $\mathbf{1 5}$ \\
\hline Total & \\
\hline
\end{tabular}


The final sample size is congruent with established switch interview practices in market research, which have established 10 to 15 participants ${ }^{2}$ to be typically able to meet "data saturation"- data saturation occurs when "...new data tend to be redundant of data already collected...[and] the researcher begins to hear the same comments again and again..." (Grady, 1998: 26), and thus additional interviews no longer reveal fresh insights (Sandelowski, 2008). If however the researcher uncovers new data, interviews would continue until information becomes redundant ${ }^{3}$.

In academic qualitative research, while the adequate sample size for qualitative research is still an ongoing debate ${ }^{4}$, there is, nevertheless, common agreement that sample size is not fixed and depends on the nature of research, what the research aims to do, and type of research question(s) being asked (Cobern and Adams, 2020) and that there is always judgement involved. That judgement, however, must also be explained (Cobern and Adams, 2020).

In regard to the sampling of this paper, the key judgment must be based on the aim of the study. The aim of this study is to propose and introduce a new approach for voter segmentation, which focuses not on voter or party traits but on voter needs, as well as a new tool, switch interviewing, that can help us put that approach to work in the field. As such, the paper doesn't claim to statistically represent (or uncover) all opinions /needs of the opposition electors who lean towards the new parties; it certainly does not claim to have scanned all opposition voters in Turkey. It does claim however having proposed a new way of studying how political preferences are formed.

The in-depth switch interviews resulted in three categories of voter needs that electors who consider voting for the new parties are trying to address. It should be emphasized that these categories have not

\footnotetext{
${ }^{2}$ Results from switch interviews are used by companies to determine design of products as well as strategies for competition and marketing, which may cost up to millions of dollars. Therefore, the stakes in market research sampling are no less serious than those in other types of research.

${ }^{3}$ Following Morse (1995), it should also be noted that, even if saturation is not reached, it doesn't make the findings invalid. Rather, it simply means that topic is not fully explored the issue (see also Townsend, 2013).

${ }^{4}$ For grounded theory, some scholars have suggested 30 to 50 (see for example, Morse, 1994) and some 20 to 30 participants (see for example, Creswell, 1998); whereas in phenomenological research, 6 to 25 participants are commonly accepted as a reasonable range for reaching saturation (Creswell, 1998 and Morse 1994).
} 
been determined prior to data collection; rather they emerged from the data as the researcher analyzed the interviews.

Drawing from these needs, I profile three voter relational voter profiles: the Boxer, the Pragmatist and the Visionary. The below scheme demonstrates the number of respondents in each relational segment. It also shows how each new relational segment covers various political identities; for example, the category of Boxer is composed of electors who self-identify as Kemalist, Social-democrat, Conservative, Islamist, and Nationalist. Similarly, the new relational segments are composed of respondents coming from a variety of socio-demographic attributes.

Table 2. New Relational Segments

\begin{tabular}{|c|c|c|c|}
$\begin{array}{c}\text { New Relational } \\
\text { Segments }\end{array}$ & $\begin{array}{c}\text { Number of } \\
\text { Respondents }\end{array}$ & Self-identification \\
\hline The Boxer & 7 & Kemalist/Social-democrat; Conservative/Islamist; Nationalist \\
\hline The Pragmatist & 6 & Kemalist/Social-democrat; Conservative/Islamist; Nationalist \\
\hline The Visionary & 2 & Nationalist; Kemalist/Social-democrat \\
\hline
\end{tabular}

\section{ANALYSIS AND DISCUSSION: THE BOXER, THE PRAGMATIST AND THE VISIONARY}

\section{The boxer: Knock him out on my behalf!}

The common concern for voters in this category is 'ridding the incumbent'. The content of this opposition is not ideological; the struggling moments are not found, for example, in fears against Islamization or growing authoritarianism. Instead, timelines demonstrate in common a struggling moment triggered by an everyday life event — starting a family, losing a job, trying to start a business, looking for housing, having to appeal to a court among a number of other things - which make the boxer realize that 'the quality of his-her life has declined so radically that life has become intolerably difficult'.

Boxers largely narrate that after facing an economic, judicial, or welfare letdown, they have fallen into a trap of misfortune with no foreseeable exit, as exemplified below. 
Hasan, a former JDP voter and a self-identified Islamist, for example, due to the financial decay the country has been exposed in the last few years, has suffered various losses; first losing his business then not being able to secure employment.

"I used to vote for them [referring to the JDP]. But in 2018 I decided not to any longer and I voted for CHP (the main secular opposition party) ... For four years, I had a restaurant. I had 20 workers. Then everything became so expensive. I was buying oil for 100 YTL, then it was 300 YTL. I was paying workers insurance. 300 YTL then it got up to 800 YTL. I could not earn a living...I then looked for jobs. I would ask how much is the hourly wage? The guy would say 100 YTL. Then a Syrian would come and say I will do it for 50 YTL”.

Similarly, Osman, a former supporter of the JDP and a self-identified conservative, narrates that:

"I came back from military service few years back. I got married. I found a job in 15 days and I was even able to pay my wedding debts. But in the last two years [referring to 2018-2020], although I work the same hours and everything, I cannot earn a living. The cost of everything has been inflated... Cost of gas and electricity. But our salaries remain the same. Minimum wage remains the same. But I stay at my current job because at least it pays for my social insurance... I can't get mad at my employer either. There is no customer. All stores are being closed down one after the other on our street. What can he do if there is no customer?"

Ahmet, a self-identified nationalist who also voted for the JDP in the past, on the other hand, exemplifies how interacting with bureaucratic institutions and processes may impact electoral support for the incumbent. A confrontation with the state machinery, where citizens feel wronged and devalued result in alienation from the ruling party:

"I want to be able to get things done whenever I deal with any judicial body. Even when you get the smallest traffic ticket, you don't have any one whom you can address. Like I got a traffic ticket and I then appealed it to the court. I ended up paying interest because there is no one to 
whom you can talk to. Nobody takes you seriously...they [referring to bureaucracy] don't give a damn!"

After this experience, which led Ahmet to question whether the JDP was running the country as well as he originally had thought, he was exposed to financial strains, again via bureaucratic institutions. He finally decided to vote for one of the new parties:

"I have been in the food sector in the last 3 years. I now own a small corner store. Every year they want us to renew our TEKEL license (license for alcoholic beverages and tobacco). I now have to pay 450 TL...again! Every year, there is some shenanigan like that. The government is crushing us under such things..."

As these examples demonstrate, the boxer holds the incumbent responsible for creating a trap of misfortune and finds the solution in ridding the incumbent at whatever cost, as expressed by another participant: “...they need to go, otherwise our lives will simply be chaos." With such intense personalized feelings against the incumbent, the boxer is the steadfast opposition vote.

The boxer is also very utilitarian. In the next election, the single issue for the boxer will be power orientation. That is, having their main concern as ridding the incumbent, the boxer will likely lean towards whatever rival seems to have the greatest chance to knock off the government.

This strategic voting also suggests that they will have little party loyalty. Until the elections, boxers may express support to certain parties (as is, newly founded parties) when they show up in surveys. However, their final decision will most likely not come until election time, as expressed by Ahmet:

"Around the election, we will know the strongest opponent... that's who I am going to vote for."

As for the boxer little else other than power will matter, they are likely not the part of the population that would pressure the opposition for substantial reform or a new political ethos. Their immediate agenda is focused on the quantity of electoral support rather than its content, such as anticipated 
performance on democracy, women's rights, or good governance. Hence, while the boxer votes will be fundamental to win over the incumbent, society cannot rely on them in shaping post-JDP's Turkey.

\section{The pragmatist: Win-win scenarios by dismantling clientelism}

Like that of the boxer, the pragmatist opposition to the JDP is not driven by ideological dissent, Pragmatists commonly struggle with a feeling of unjust exclusion from collective goods, monetary and non-monetary. They relate this exclusion to the hyper-clientelism (yandaşllk) they think is created by the JDP government, monopolizing not just lucrative opportunities but such average opportunities as government-backed housing, educational opportunities, or access to Corona Bonds and SME funds.

This struggle in turn creates the urgent need to dismantle the clientelist structure itself. Importantly, the pragmatist is not oriented to becoming new clients (yandaş) replacing existing ones. Instead they are oriented towards dismantling the binary system of "yandaş" versus others for once and all.

The underlying sentiment of this impulse is not idealism or altruism. On the contrary, this is a very pragmatist attitude. As average citizens, pragmatists have first-hand experienced the dead end of clientelism, including those who once used to be in client nests: the circle always becomes smaller with inclusion criteria becoming more selective than mere partisanship. The solution, they think, is dismantling clientelist attitudes so that individual prosperity would not be subject to parting in political or ideological networks.

Ekrem, a self-identified nationalist, epitomizes this pragmatist attitude as follows:

"In 2016, I applied to state grants to establish a barn in Bayburt. I met all the eligibility criteria. But I did not get it... I returned to Ankara. Then I applied for KOSGEB (Small and Medium Enterprises Development Organization). They also had a set of criteria and I met all that as well. To start a business. But then this time they told me that criteria has recently changed. Now they say glassware sector cannot apply and that you are supposed to have engineers... I am a small business. How am I supposed to hire an engineer? I am a member of the JDP. Let's say they 
support their own. But I still could not get anything. As a small business owner, as a member of the JDP, I cannot get anything. Now I am no longer looking at this from my own perspective. Such rights should be given to anyone who deserves it. It should not be based on patronage."

Importantly, this impulse against clientelism includes a reversal of the pragmatist's own ideological biases. For example, those who self-identify as religious conservatives state that they will no longer vote based on religious versus secular rhetoric. Mehmet, a self-identified Islamist who refrained from voting in the last election, states that:

"In 2018 because of the Pastor Bronson crises, I had to close my restaurant. Then the government let him go. Now I have to work in two jobs and I never see my family... No more partisanship. I won't look at religion or Atatürk [referring to CHP]. Whoever can get things done, we want to follow him. But he should not show favoritism to his own circle. There should no longer be this system of yandaşlık (clientelism)"

Interestingly, while the pragmatists in the survey opted for the new parties, the interviews revealed that most of them are still undecided. It makes sense that they are turned off by the parties in the Millet Coalition viewing them equally ideological hence having the risk of continuing clientelism when in power. They are, therefore, turned to the new parties as being newly founded means not having established 'a natural electoral base' yet, which would turn into new clients. However, they have their doubts and do not seem to they have found the nonpartisan leader they are looking for. This is enforced by the fact that the pragmatists focus on individual leaders and their performance rather than political parties.

In the next election, the single issue for pragmatists will likely be the anticipated performance of a candidate for the principled defense of public goods and whether he-she can establish a system where opportunities are inclusive and criteria for access to public goods is transparent. 
Zehra, a self-identified social-democrat, who voted for the nationalist party, MHP, in the past, for instance states that:

"The old me would not have voted for the CHP (the main secular opposition party) because I am a conservative woman. But I did in the last election [referring to 2018]. Because they seemed like the strongest rival that can rid of the JDP... But now, for me there is no longer left or right. I want a politician who would simply stand with his nation, defend his nation. I will absolutely not have favor someone just because he is a conservative [sağcl]. now I want our country to have rule of law. Everyone is hostile against one another; nobody trusts to another. This has to end."

Considering various surveys, the last two years, which consistently show the undecided voter bloc having reached historical highs—some analysts pointing to even \%40 (TRsputniknews, 2019)—, it is probable that the pragmatists make up a big part of the opposition votes. Pragmatists, therefore, may play an important electoral role against the incumbent, Additionally, with their focus on content, differentiating them from the boxers, they will also be important for shaping post-JDP's Turkey's in a qualitative sense as well, especially for pressuring the opposition to move away from partisanship and bring about justice and rule of law.

\section{The visionary: Make Turkey great for once and all}

The visionary has a historical concern rooted in the formation of modern Turkey, a need that could not been materialized so far: make Turkey great by joining her to the league of rich democracies!

What now revives this historical job and makes it a burning one is the visionary's belief that Turkey is being exposed to a mounting number of crises, especially international ones. For the visionary, such crises are caused by inept and cocksure policies of the leadership and have direct costs to citizens at home. For example, one struggling moment for the visionary was the Pastor Branson crises, which, by plummeting the Turkish Lira, caused some to lose jobs and some to close businesses, as put by Ender, a self-identified nationalist who voted for the IYİ Parti in the last election exemplifies: 
"Pastor Bronson crises, with its back and forth...the government severely devalued Turkish Lira in just one night to a level where companies bankrupted..."

The visionary basically thinks a leader can make or break a country, again, as put by Ender:

"They represent us...and they can either make us or break us. They can upgrade the county or get us all into a war through their policies or discourses."

This also shows that they are leader-oriented, ascribing a very traditional role to the leader: a leader determines a country's fate:

"Politicians impact our lives directly. Whether we like of not, those who run the county are the politicians. They take a decision and the whole education system or conditions of economy. Since we cannot do that [referring to change] ourselves, we are looking for a leader to do it on our behalf".

The visionary is in quest of radical change. The long-term opposition is not viewed as being able to lead such change as they are associated with the old system. Visionaries find the solution in bringing in a new leader who can be a game changer and take Turkey to the next level of economic welfare and redeem her international status.

The single issue in the next election for them, therefore, will be competence: Is there a leader with credentials and the vision to upgrade Turkey?

As such, unsurprisingly, the visionary is the segment that is most engaged with the question of "how should post-JDP's Turkey look like" and they are looking for what I call a 'purpose-leader' whose one and single purpose would be nailing the job of 1making Turkey a great nation'. If one of the new parties can claim such clear purpose, visionaries would not even seek other options. This would mean high party loyalty, long-term support, and an army of volunteers, similar to Obamaphiles or Macron's Le Movement, that would enable exponential growth eventually. 


\section{CONCLUSION}

The paper's core idea is that to understand electoral behavior, we need to look beyond sociodemographic traits and group affinities ('structure') and atomistic interests ('agency') and focus our inquiry on what concerns and needs voters are trying meet in a particular system of relations.

This approach to electoral behavior revealed that the 20 years of the JDP's rule in the country has created three common concerns among those who lean towards the new parties: the JDP and the current political system is perceived (1) to have failed the populace across economy, welfare, and justice, (2) to have created an unprecedented level of clientelism, and (3) to have inhibited Turkey's potential to finally join the league of rich democracies.

Importantly, each category brings together voters from various ideological partisan and sociodemographic backgrounds. Conventional models could not have captured these convergences and would expect these voters to have completely different political preferences.

These findings are important not only to understand the causal drivers for support to the new parties in Turkey, but they also give us clues into the future political debates and shifts in the country. Whether existing or new political actors will manage to cater to those needs is to be seen; however, elements of these concerns will most likely influence future elections and struggle for democracy in Turkey.

The aim here is not to narrow voter segmentation to a single right approach. Nor the study claims to uncover all opinions /needs of the opposition electors who lean towards the new parties; it certainly does not claim to have scanned all opposition voters in Turkey. Rather, the paper aims to push the boundaries of the existing models by adopting a relational thinking and a new tool, switch interviewing, and build a new model for voter segmentation.

This push is necessitated in part by the changing nature of 'being political', as evinced globally in youth movements, from Arab Spring to Occupy LA to the Umbrella Movement in Hong Kong, which all came 
Re-Segmenting Opposition Votes in Turkey

Using a Relational Approach: the Boxer,

the Pragmatist, and the Visionary

forward with Do-It-Yourself/DIY-style (see Pickard 2019, for more) of political engagement and a new definition of citizenship.

Finally, the paper makes two original contributions. It proposes a new model for voter segmentation using a relational approach and introduces a new methodological tool, switch interviews, to qualitative research. 


\section{ÖZET}

Yaklaşık son on yıldır, tüm dünyada "kestirilemeyen" seçim sonuçları istisna olmaktan çıkıp norm haline geldi. Kasi Said'in 2015 Tunus seçimlerindeki yükselişi, İngiliz vatandaşlarının Avrupa Birliği'nden ayrılma kararı (2016), Sinn Féin'in 2020 İrlanda'da iktidara gelmesi ve İmamoğlu'nun, İstanbul'da Ümraniye gibi muhafazakarlığın kalesi olarak görülen bölgelerde bile çoğunluk desteği alması (2018) sadece birkaç örnek. Her ne kadar siyasal endüstri ilk tepki olarak bu seçimleri tuhaf, şok, ve seçim-depremi gibi terimlerle tanımlandıysa da bir süre sonra bu sonuçların 'aslında' neden mantıklı olduğuna ilişkin açıklamalar hızlı bir şekilde ortaya kondu. Örneğin İrlanda'da Féin'in galibiyeti barınma ve sağlık hizmetleri konusundaki büyük sıkıntılara atfedildi.

Akla gelen ve mevcut çalışmanın da ortaya konmasına sebep olan soru şu: "siyasi endüstri birçok ülke ve birçok farklı seçimde, neden bu 'aslında' mantıklı olan sonuçları yakalayamadı?

Bu çalışma, cevabın 'ölçüm hatalarında' değil, seçimleri belirleyen etkenler olarak 'neyi ölçtüğümüz' ile ilgili karar verirken yaptığımız hatada olduğunu savunuyor; bu karar ise seçmen davranışı literatürünün hâkim teorik varsayımlarında gizli.

Tarihsel olarak, seçmen davranışı çalışmalarını üç teorik model şekillendirmiştir: sosyolojik model, psiko-sosyal model ve rasyonel seçim modeli. Ancak her üç modelde sosyal teorinin klasik 'yapıya karşı aktör' ikiliği üzerine inşa edilmiştir. Diğer değişle, siyasi tercihler ya bireylerin sahip olduğu yapısal özelliklerce belirlenir (cinsiyet, yaş, din, eğitim, ideoloji, vs) ya da sanki toplumdan ve ilişkilerden tamamen bağımsız olduğu varsayılan bireylerin rasyonel çıkarlarınca belirlenir.

Söz konusu modellerden farklı olarak, bu çalışma seçmen davranışını ilişkisel bir yaklaşımla ile incelemiş ve Türkiye özelinde yapılan bir nitel araştırma ile yeni bir seçmen kümelemesi (segmentation) modeli oluşturmuştur. 
İlişkisel yaklaşım ile özellikle üç şeyi kastediyorum: (1) ‘yapıya karşı aktör’ ikiliğinden çıkmak (2) sosyal eylem ve fenomeni süreçsel olarak (processual) ve (3) bir ilişkiler matrisine gömülü (embeddedness) olarak anlamak.

Bu ilişkisel bakış açısında, analiz birimi ne seçmenin sahip olduğu geniş yapısal özellikler (etnik köken, din, ideoloji, cinsiyet, vb.) ne de seçmenlerin atomistik olduğu varsayılan hesaplamalarıdır. Bunun yerine, analizin odağ seçmenlerin belirli bir ilişkiler sistemi içinde ortaya çıkan gerçek ihtiyaçlar ve endişeleridir (çözülmesi gereken bir sorun veya yapılacak bir ilerleme).

İlişkisel analizin alanda uygulanması için bir derinlemesine mülakat tekniği olan 'switch (kayma) mülakatları' kullanılmıştır. Sosyal bilim literatüründe henüz istifade edilmemiş olan bu teknik, özelikle ilişkisel alan çalışmaları için oldukça mütenasiptir.

Switch mülakatları, seçmenin bir karara varırken yaşadığı gerçek süreçleri (veya olayları silsilesini) takip ederek bir zaman çizelgesi oluşturur. Bu şekilde seçmenin sosyal özelliklerini veya bireysel hesaplamalarını incelemek yerine, hem siyasi tercih kararına dahil olan süreçleri hem de bu kararın gömülü olduğu bağlam ve ilişkiler ağını inceler. Böylece hem siyasi tercihlerin altında yatan nedensellik ilişkilerini hem de seçim kararının 'diğer tüm şeylerle' (ilişkiler, alanlar, ve aktörler matrisi) nasıl bir arada durduğunu (how things hang together) ortaya çıkarır: örneğin, yalnızca siyasi seçkinler ve medya ile olan etkileşim değil aynı zamanda aile, çalışanlar, işverenler veya bürokratik kurumlar, tüketim ve pazarlar, boş zaman ve günlük yaşam ve bir dizi başka etkileşim.

Switch mülakatları 10-15 katılımcıyla gerçekleştirilir. Bu çalışmada da switch mülakatları 15 katılımcı ile yapılmıştır. Katılıcımlar Mart 2020'de yapılmış olan ulusal bir anketten "yarın bir seçim olsa yeni kurulan partilerden birine oy veririm" diyen seçmenlerden oluşmaktadır. Bu seçmenlerin bir kısmı daha önceki seçimlerde Cumhur Koalisyonu partilerine bir kısmı da Millet Koalisyonu partilerine oy vermiştir. 
Dolayısı ile bulgular, tüm muhalefet seçmenlerini değil, sadece hem mevcut iktidara hem de ana akım muhalefet partilerine uzak olan ve yeni bir siyasi çözüm arayanları temsil ediyor. Bu bilinçli bir seçimdir. Yeni bir siyasi çözüm arayışında olan muhalefet seçmenlerinin ihtiyaçlarını ve endişelerini anlamak ve olası siyasi değişimin ve siyasi eğilimlerin içeriği ve yönü hakkında ipuçları verecektir.

Mülakatlar yeni partiler için oy vermeyi düşünen seçmenlerin üç ana endişe veya ihtiyacı olduğunu göstermiştir: 1) Boksör (yaşadıkları kayıpların sorumlusunu hükümetin başarısızlıkları olarak gören ve bu kayıpların son bulması için hükümeti tek bir vuruş ile düşürecek bir siyasi aktör arayanlar); 2) Pragmatist (daha önce benzeri görülmemiş bir yandaşlık sistemini yaratıldığını düşünüp, bireysel refahın sosyal refah olmadan oluşamayacağını ve bu yüzdende kendilerini yeni yandaşlar yapacak birindense yandaşlık zihniyetini tamamen ortadan kaldıracak bir siyasi aktör arayanlar); 3) Vizyoner (Türkiye'yi içinde bulunduğu düşünülen yüksek siyasi ve ekonomik risklerden çıkartıp refah sahibi demokrasiler ligine çıkaracak bir değişim lideri arayışı içinde olanlar).

Bu kümelerin her biri, geleneksel modellerce karşıt oy seçeneklerine sahip olması beklenen kimlikler de dahil (örn. İslamcı-Kemalist), çeşitli siyasi kimlikleri ve çeşitli sosyo-demografik özelliklere sahip seçmenleri bir araya getiriyor.

Makale seçmen kümelemesini tek bir doğru yaklaşıma indirgemeyi değil; seçim davranışına ilişkin mevcut modellerin sınırlarını zorlamayı ve uygulanabilir bir analitik alternatif önermeyi amaçlamaktadır. Nitekim alternatif modellere olan ihtiyaç politik oluşun ve vatandaşlık tanımın hızla değiş̧iği bir dünyada - ki Arap Baharı'ndan Occupy LA'ya ve Hong Kong'daki Umbrella Hareketi'ne kadar olan küresel gençlik hareketlerinde bu değişim barizdir-, bu dünyayı anlamak için zaruri hale gelmiş̧ir. Son olarak, ilişkisel bir yaklaşım kullanarak seçmen kümelemesi için yeni bir model önererek ve nitel araştırmaya yeni bir metodolojik araç sunarak, makale hem niteliksel araştırma hem de seçmen davranışı literatürüne iki orijinal katkı yapıyor. 


\section{REFERENCES}

Abbott, A. (1995). Things of Boundaries. Social Research, 857-882.

Abbott, O. (2020). The Self, Relational Sociology, and Morality in Practice. Springer International Publishing.

Antunes, R. (2010). Theoretical Models of Voting Behaviour. Exedra, 4, 145-170.

Becker, H. (1966). Introduction. In C. Shaw (Ed.), The Jack Roller (pp. v-xvii). Chicago: University of Chicago Press.

Boudon, R. (1998). Limitations of Rational Choice Theory. American Journal of Sociology, 104(3), 817-828.

Bourdieu, P., Wacquant, L. J. (1992). An Invitation to Reflexive Sociology. University of Chicago Press.

Campbell, A., Converse, P. E., Miller, W. E. and Stokes, D. E. (1960). The American Voter. Chicago: The University of Chicago Press.

Christensen, C., Day, L. E. (2016). Integrating around the Job to be Done. Harvard Business School.

Christensen, C. M., Ojomo, E., Dillon, K. (2019). The Prosperity Paradox: How Innovation can Lift Nations out of Poverty. Harper Collins.

Cobern, W. W., Adams, B. A. (2020). When Interviewing: How Many is Enough?. International Journal of Assessment Tools in Education, 7(1), 73-79.

Coleman, J. S. (1986). Interests and Collective Action: Studies in Rationality and Social Change. Cambridge University Press

Creswell, J. W. (1998). Qualitative Inquiry and Research Design: Choosing among Five Traditions. Sage.

Crossley, N. (2011). Towards Relational Sociology. London: Routledge.

Dalton, R. J. (2000). The Decline of Party Identifications. In Dalton, Russell J. and Wattenberg, Martin, P. (Eds.), Parties without Partisans. Political Change in Advanced Industrial Democracies (pp. 19-36). Oxford: Oxford University Press.

della Porta, D. (2018). Radicalization: A Relational Perspective. Annual Review of Political Science, 21, 461-474. 
Dépelteau, F. (2008). Relational Thinking: A Critique of Co-Deterministic Theories of Structure and Agency. Sociological Theory, 26(1), 51-73.

Desmond, M. (2014). Relational Ethnography. Theory and Society, 43(5), 547-579.

Donati, P. (2011). Relational Sociology. A New Paradigm for the Social Sciences. London: Routledge.

Downs, A. (1957). An Economic Theory of Political Action in a Democracy. Journal of Political Economy, 65(2), 135-150.

Elff, M., Roßteutscher, S. (2016). Religion. In Arzheimer, K., Evans, J., \& Lewis-Beck, M. S. (Eds.), The Sage Handbook of Electoral Behaviour (pp.199-219). Sage.

Elias, N. (1978). What is Sociology?. Columbia University Press.

Elster, J. (1989). Nuts and Bolts for the Social Sciences. Cambridge University Press.

Erikson, R. S. (2004). Macro vs. Micro-Level Perspectives on Economic Voting: Is the Micro-Level Evidence Endogenously Induced?. Political Methodology Meetings [Presentation]. Stanford University.

Emirbayer, M. (1997). Manifesto for a Relational Sociology. American Journal of Sociology, 103(2), 281-317.

Feldman, S., Johnston, C. (2014). Understanding the Determinants of Political Ideology: Implications of Structural Complexity. Political Psychology, 35(3), 337-358.

Fowler, C. (2013). The Emergent Past: A Relational Realist Archaeology of Early Bronze Age Mortuary Practices. Oxford University Press.

Fuchs, S. (2009). Against Essentialism: A Theory of Culture and Society. Harvard University Press.

Gidengil, E., Karakoç, E. (2016). Which Matters More in the Electoral Success of Islamist (Successor) Parties-Religion or Performance? The Turkish Case. Party Politics, 22(3), 325-338.

Grady, M. P. (1998). Qualitative and Action Research: A Practitioner Handbook. Bloomington: Phi Delta Kappa Educational Foundation.

Green, D. P., Baltes, S. (2016). Party Identification: Meaning and Measurement. In Arzheimer, K., Evans, J., \& Lewis-Beck, M. S. (Eds.), The Sage Handbook of Electoral Behaviour, Vol. 2, 287312. Sage. 
Gupta, A. (2012). Red Tape: Bureaucracy, Structural Violence, and Poverty in India. Durham: Duke University Press.

Horn, M. B., Moesta, B. (2019). Choosing College: How to Make Better Learning Decisions throughout Your Life. John Wiley \& Sons.

Kasapoğlu, A. (2019). A Road Map for Applying Relational Sociology. Advances in Social Sciences Research Journal, 6(1), 448-488.

King, A. (2004). The Structure of Social Theory (1st ed.). London: Routledge.

Kinder, D. R., Kalmoe, N. P. (2017). Neither Liberal nor Conservative: Ideological Innocence in the American Public. University of Chicago Press.

Kurzman, C., Naqvi, I. (2010). Do Muslims Vote Islamic?. Journal of Democracy, 21(2), 50-63.

Lazarsfeld, P. F., Berelson, B., Gaudet, H. (1968). The People's Choice. Columbia University Press.

Lipset, S., Rokkan, S. (1967). Cleavage Structures, Party Systems, and Voter Alignments: An Introduction. In S. Lipset, S. Rokkan, (Eds.), Party Systems and Voter Alignments: Cross National Perspectives (pp. 1-64). New York: Free Press.

List, C., Spiekermann, K. (2013). Methodological Individualism and Holism in Political Science: A Reconciliation. American Political Science Review, 107(4), 629-643.

Lupton, R. N., Enders, A. M. and Jacoby, W. G. (2012). Ideology and Core Values. In Arzheimer, K., Evans, J., Lewis-Beck, M. S. (Eds.), The Sage Handbook of Electoral Behavior, Vol.2, 491521 , Sage.

Mardin, Ş. (1973). Center-Periphery Relations: A Key to Turkish Politics?. Daedalus, No.102, 169-190.

Marcus, G. E. (1998). Ethnography through Thick and Thin. Princeton University Press.

McGann, A. (2016). Voting Choice and Rational Choice. In Oxford Research Encyclopedia of Politics. https://oxfordre.com/politics/view/10.1093/acrefore/9780190228637.001.0001/acrefore9780190228637-e7-9.

McClurg, S. D., Young, J. K. (2011). Editors' Introduction: A Relational Political Science. PS: Political Science and Politics, Paper (45): 39-43. http://opensiuc.lib.siu.edu/pn_wp/45.

Miller, W. E., Shanks, J. M., Shapiro, R. Y. (1996). The New American Voter. Harvard University Press. 
Morse, J. M. (1994). Designing Funded Qualitative Research. In Denizin, N. K., Lincoln, Y. (Eds.) Handbook of Qualitative Research (2nd Ed), pp. 220-235. Sage.

Morse, J. M. (1995). The Significance of Saturation. Qualitative Health Research, 5(2): 147-149.

Öniş, Z. (2007). Conservative Globalists versus Defensive Nationalists: Political Parties and Paradoxes of Europeanization in Turkey. Journal of Southern Europe and the Balkans, 9(3), 247-261.

Pickard, S. (2019). Politics, Protest and Young People: Political Participation and Dissent in $21^{\text {st }}$ century Britain. Springer.

Powell, C., Dépelteau, F. (2013). Introduction. Powell, C., Dépelteau, F. (Eds.). Conceptualizing Relational Sociology: Ontological and Theoretical Issues, (pp.1-12). Springer.

Sandelowski M. (2008). Theoretical Saturation. In Given, L.M. (Eds). The SAGE Encyclopedia of Qualitative Research Methods, p. 875-876. Sage.

Somers, M. R., Gibson, G. D. (1994). Reclaiming the Epistemological Other: Narrative and the Social Constitution of Identity. In C Calhoun (Ed.), Social Theory and the Politics of Identity, (p. 37 99). Oxford: Blackwell.

Somers, M. R. (1998). 'We're No Angels': Realism, Rational Choice, and Relationality in Social Science. American Journal of Sociology, 104, 722-784.

Tekin Babuç, Z., Müjdat, A. (2019). A Relational Sociological Analysis of Syrian Students' Experiences in Osmaniye Province on Integration to Higher Education Process. International Journal of Eurasia Social Sciences, Vol: 10, Issue: 37, 833-848.

TR Sputniknews, (2019). Kararsız Seçmen Yüzde 40'a Çıktı. https://sptnkne.ws/6Yfq (Last accessed January 2021).

Townsend, K. (2013). Saturation and Run Off: How Many Interviews are Required in Qualitative Research. In ANZAM Conference 2013.

Treier, S., Hillygus, D. S. (2009). The Nature of Political Ideology in the Contemporary Electorate. Public Opinion Quarterly, 73(4), 679-703.

Tsing, A. (2005). Friction: An Ethnography of Global Connection. Princeton: Princeton University Press. 
Van der Brug, W., Berkhout, J. (2015). The Effect of Associative Issue Ownership on Parties' Presence in the News Media. West European Politics, 38(4), 869-887.

Von Schoultz, Å. (2017). Party Systems and Voter Alignments. In Arzheimer, K., Evans, J., LewisBeck, M. S. (Eds.). The Sage Handbook of Electoral Behaviour, Vol.1, 30-55. Sage.

Yılmaz, O., Sarıbay, S. A., Bahçekapılı, H. G., \& Harma, M. (2016). Political Orientations, Ideological Self-Categorizations, Party Preferences, and Moral Foundations of Young Turkish Voters. Turkish Studies, 17(4), 544-566.

Zielinski, J. (2002). Translating Social Cleavages into Party Systems: The Significance of new Democracies. World Politics, 54, 184-211. 